\title{
Analisis Komparatif Kinerja Pada Lembaga Perkreditan Desa Kecamatan Mengwi dengan Metode Balanced Scorecard
}

\author{
I Gusti Ayu Agung Meilinda Setia Dewi ${ }^{1}$ \\ I Wayan Suartana ${ }^{2}$ \\ ${ }^{1}$ Fakultas Ekonomi dan Bisnis Universitas Udayana (Unud), Bali, Indonesia \\ email: meilindadewi18@gmail.com/ Telp: +6285338334150 \\ ${ }^{2}$ Fakultas Ekonomi dan Bisnis Universitas Udayana (Unud), Bali, Indonesia
}

\begin{abstract}
ABSTRAK
Penelitian ini bertujuan untuk mengetahui perbedaan kinerja LPD di Kecamatan Mengwi dengan metode balanced scorecard dengan mengambil sampel 20 LPD menggunakan metode proportionate stratified random sampling. Penilaian kinerja dari perspektif keuangan diukur dengan rasio ROI, perspektif pelanggan diukur dengan tingkat kepuasan nasabah, proses bisnis internal dan pertumbuhan dan pembelajaran diukur dengan tingkat kepuasan karyawan, respoden pada penelitian ini, yaitu 75 karyawan LPD dan 100 nasabah LPD yang diambil menggunakan simple random sampling. Pengujian hipotesis pada penelitian ini menggunakan uji ANOVA. Penelitian ini diharapkan meberikan implikasi bagi pemangku kepentingan seperti, karyawan LPD, nasabah LPD, dan pengurus LPD. Berdasarkan hasil analisis terdapat perbedaan dari kinerja pada LPD Kecamatan Mengwi dari perspektif keuangan, perspektif pelanggan, perspektif proses bisnis internal, dan perspektif pertumbuhan dan pembelajaran.

Kata kunci: Balanced Scorecard, Penilaian Kinerja, LPD
\end{abstract}

\begin{abstract}
This study aims to determine the differences in the of LPD in Mengwi district by balanced scorecard method used 20 LPD samples using proportionate stratified random sampling method. Performance appraisal from financial perspective is measured by ROI ratio, customer perspective measured by customer satisfaction level, internal business process and growth and learning measured by employee satisfaction level, respresent in this research are 75 LPD employees and 100 LPD customers taken using simple random sampling. Hypothesis testing in this research using ANOVA test. This research is expected to implies the stakeholders such as LPD employees, LPD customers, and steward of LPDs. Based on the results of the analysis there are differences in performance in LPD Mengwi district from financial perspective, customer perspective, internal business process perspective, and growth and learning perspective.
\end{abstract}

Keywords: Balanced Scorecard, Performance Appraisal, LPD

\section{PENDAHULUAN}

Undang-Undang Lembaga Keuangan Mikro (LKM) No. 1 Tahun 2013, lembaga keuangan mikro adalah lembaga keuangan yang khusus didirikan untuk memberikan jasa pengembangan usaha dan pemberdayaan masyarakat, baik 
melalui pinjaman atau pembiayaan dalam usaha skala mikro kepada anggota dan masyarakat, pengelolaan simpanan maupun pemberian jasa konsultasi pengembangan usaha yang tidak semata-mata mencari keuntungan. Salah satu Lembaga Keuangan Mikro yang ada di Bali adalah Lembaga Perkreditan Desa yang selanjutnya disebut LPD (Gunawan, 2009). Berdasarkan Peraturan Daerah Provinsi Bali No.3 Tahun 2017 lembaga perkreditan desa merupakan kelembagaan desa pakraman yang menjalankan fungsi keuangan desa pakraman untuk mengelola potensi keuangan desa pakraman. Peraturan Daerah Provinsi Bali No.3 Tahun 2017 juga menjelaskan LPD memberikan manfaat baik secara ekonomi, sosial, dan budaya bagi masyarakat desa.

Kepemilikan lembaga keuangan ini adalah milik desa pakraman di Bali yang dengan sendirinya adalah milik masyarakat desa maka dari itu baik debitur maupun krediturnya adalah masyarakat desa setempat. Hal ini merupakan keunikan yang dimiliki sekaligus tantangan bagi LPD agar memperhatikan kinerja dalam menjaga eksistensinya. LPD tentu memiliki tujuan yang sama dengan lembaga perbankan lainnya yaitu untuk mencari keuntungan yang nantinya bisa dikelola untuk kepentingan warga desa (Susila, 2016). Seiring dengan perkembangan teknologi yang terjadi saat ini menimbulkan adannya persaingan dalam berbagai aspek. Tidak hanya bersaing dalam memperoleh sumber daya, namun juga dalam hal produksi, pemasaran, serta interaksi dengan konsumen (Putri dan Wirasedana, 2015). Perkembangan teknologi informasi menciptakan lingkungan yang kompetitif, di mana LPD harus memperhatikan kinerja untuk tetap bertahan di dalam persaingan (Winata dan Astana, 2017). 
Ukuran kinerja keuangan LPD pada umumnya dilihat dari kemampuan dalam menghasilkan laba (Ariani dan Ardiana, 2015). Berdasarkan data yang diperoleh dari LPLPD Kabupaten Badung. Total laba 38 LPD se-Kecamatan Mengwi tahun 2014-2016 cenderung meningkat. Semakin tinggi kemampuan menghasilkan laba, diasumsikan semakin kuat LPD untuk dapat bertahan dalam kondisi ekonomi yang kompetitif (Antara dkk, 2014). Laba yang meningkat menunjukkan pencapaian yang baik pada kinerja keuangan perusahaan. Pencapaian yang baik pada perspektif keuangan tidak dapat menggambarkan kinerja LPD secara keseluruhan. Kinerja dapat dibagi menjadi dua, yaitu keuangan dan non kuangan (Öztürk dan Coskun, 2014). Penilaian kinerja tidak hanya dilihat dari aspek keuangan seperti total laba yang diperoleh, namun juga dari aspek non keungan seperti sumber daya manusianya, karena LPD berfungsi sebagai penggerak ekonomi di pedesaan yang perkembangannya sangat pesat, maka sudah sepantasnya dikelola secara profesional oleh sumber daya manusia yang berkompeten sehingga LPD mampu bersaing dan memberikan dampak positif terhadap desa adatnya. Sistem pengukuran kinerja yang efisien dan akurat berfungsi sebagai alat yang berguna yang memungkinkan manajer mengendalikan, memanta dan memperbaiki proses dan kinerja perusahaan (Lin et al., 2014). Penilaian kinerja memudahkan perusahaan untuk menilai apakah perusahaan telah mencapai tujuannya dan mengalami peningkatan kinerja dari segala aspek setiap tahunnya (Sukma dan Krisnadewi, 2013).

Al-Najjar dan Kalaf (2012) mengatakan bahwa, pengukuran kinerja dengan bedasarkan aspek keuangan saja akan membuat LPD berorientasi pada 
tujuan jangka pendek, hanya menggambarkan tangible assets dan kurang memiliki kemampuan prediktif terhadap kelangsungan hidup perusahaan dalam jangka panjang. Oleh karena itu, perspektif non-keuangan dianggap sebagai bagian yang perlu diperhatikan, sehingga dapat mendongkrak kinerja keuangan yang merupakan keinginan utama dari pemegang saham (Susila, 2016). Pengukuran kinerja berdasarkan aspek non-keuangan sering diabaikan karena dianggap sebagai sesuatu yang sulit untuk dilakukan pengukurannya dan pengukuran aspek non-keuangan membutuhkan biaya serta waktu yang banyak (Sari dan Putri, 2014). Pengukuran kinerja pada LPD sangat penting dilakukan karena LPD merupakan lembaga keuangan yang menghimpun dan menyalurkan dana warga desa serta agar dapat meningkatkan tata kelola dan kinerja LPD.

Kaplan dan Norton pada tahun 1997 kemudian mengeluarkan sebuah konsep untuk mengukur kinerja tidak hanya dari perspektif financial namun juga dari perspektif non-financial suatu perusahaan yang dinamakan balanced scorecard (Christina dan Sudana, 2013). Menurut Rasmini (2009), balanced scorecard merupakan suatu metode yang mengungkapkan betapa pentingnya untuk melihat kinerja aspek keuangan dan non-keuangan guna tercapainya keseimbangan dalam pengukuran kinerja. Balanced scorecard adalah sistem pengelolaan yang dapat membantu organisasi untuk menjelaskan visi, dan strategi serta menerapkan dalam operasinya (Suartana dan Ariyanto, 2012). Menurut Dudin dan Frolova (2015), balanced scorecard merupakan alat yang efektif untuk mengelola strategi bisnis saat ini. Balanced scorecard dan strategi berjalan beriringan, balanced scorecard merupakan model yang efektif untuk digunakan 
menilai tingkat efisiensi perusahaan dan balanced scorecard juga merupakan model yang efektif dalam memandu manajer untuk mencapai tujuan (Domanovic, 2016). Penilaian kinerja dengan metode balanced scorecard juga dapat memberikan hasil yang lebih realistis dibandingkan dengan teknik lainnya, selain itu juga dapat meningkatkan komunikasi antar karyawan (Dincer, et al., 2016) Balanced Scorecard memiliki empat perspektif yang berimbang untuk mengukur kinerja LPD. Empat perspektif tersebut, yaitu perspektif keuangan, perspektif pelanggan, perspektif proses bisnis internal, perspektif pembelajaran dan pertumbuhan (Kaplan dan Norton, 2000:17). Penjabaran empat perspektif merupakan suatu strategi objektif yang menyeluruh dan saling berhubungan dimulai dari perspektif pembelajaran dan pertumbuhan, perusahaan mempunyai suatu strategi untuk meningkatkan produktivitas, dan komitmen personel (Begawan dan Suryanawa, 2013). Penjabaran empat perspektif balanced scorecard secara singkat menurut Mulyadi (2007:432), (1) perspektif keuangan memiliki fokus utama terhadap kinerja keuangan perusahaan. Pengukuran kinerja keuangan perusahaan menunjukan apakah sebuah perencanaan ataupun pelaksanaan strategi dapat memberikan perbaikan bagi keuntungan LPD, (2) perspektif pelanggan mempunyai fokus pada kepuasan pelanggan, (3) perspektif proses bisnis internal berfokus pada kinerja internal dalam sebuah LPD, (4) perspektif pembelajaran dan pertumbuhan berfokus terhadap kinerja personel secara keseluruhan, sumber dari proses pembelajaran dan pertumbuhan adalah sumber daya manusia, prosedur, organisasi, dan sistem.

Balanced scorecard dapat diterapkan dalam berbagai organisasi, seperti 
pada lembaga pendidikan (Poureisa, et al., 2013; Seth dan Oyugi, 2013) lembaga pemerintahan (Limbu dan Sisdyani, 2016), rumah sakit (Rasmini, dkk., 2009), perusahaan (Istiqlal, 2009; Purwandari, 2016; Wiguna dan Wirawati, 2017). Beberapa penelitian secara spesifik mengkaji perbandingan kinerja dengan metode balanced scorecard yang dilakukan oleh Visitra (2013) pada KSU Kuta Mimba dan PUSKUD Bali Dwipa, Widiastiti (2013) pada PT. BPR Mitra Balijaya Mandiri dan PT. BPR Cahaya Bina Werdhi, Panicker dan Seshadri (2013) pada bank asing di India, dan Putri dan Wirasedana (2015) pada BPR Mertha Sedana dan BPR Bali Harta Sentosa menunjukan bahwa terdapat perbedaan kinerja pada masing-masing objek yang diteliti oleh keenam peneliti tersebut dari keempat perspektif balanced scorecard yang digunakan,yaitu perspektif keuangan, perspektif pelanggan, perspektif proses bisnis internal, perspektif pembelajaran dan pertumbuhan berperan sebagai faktor pemicu kinerja manajemen.

Penelitian ini akan mengukur kinerja LPD di Kecamatan Mengwi, dengan tujuan untuk mengetahui adanya perbedaan kinerja LPD di Kecamatan Mengwi dari empat perspektif balanced scorecard, yaitu perspektif keuangan, perspektif pelanggan, perspektif proses bisnis internal, perspektif pembelajaran dan pertumbuhan. Peneliti memilih Kecamatan Mengwi karena jumlah laba di 38 LPD Kecamatan Mengwi meninggkat setiap tahunnya yang menunjukan kinerja LPD baik pada aspek keuangan dan LPD di Kecamatan Mengwi belum pernah mengukur kinerja pada aspek non keuangan, dengan demikian diharapkan penelitian ini dapat menjadi bahan referensi maupun pertimbangan dari masingmasing LPD di Kecamatan Mengwi dalam meningkatkan kinerjanya ditinjau dari 
empat perspektif balance scorecard.

Ukuran kinerja keuangan menunjukan apakah strategi, sasaran strategi, inisiatif strategi dan implementasinya mampu memberikan kontribusi dalam mengasilkan laba bagi perusahaan (Atkinson, et al., 2012:118). Hipotesis yang diajukan pada penelitian ini:

$\mathrm{H}_{1}$ : Terdapat perbedaan kinerja LPD Kecamatan Mengwi dilihat dari perspektif keuangan.

Perspektif ini mengidentifikasi pelanggan dan segmen pasar di mana unit bisnis tersebut akan bersaing serta berbagai ukuran kinerja unit bisnis di dalam segmen sasaran (Antari dan Sudana, 2016). hipotesis yang diajukan pada penelitian ini :

$\mathrm{H}_{2}$ : Terdapat perbedaan kinerja LPD Kecamatan Mengwi dilihat dari perspektif pelanggan.

Perspektif proses bisnis internal memungkinkan para manajer untuk mengetahui seberapa baik bisnis mereka berjalan, dan apakah produk dan layanannya sesuai untuk kebutuhan pelanggan (Harold dan Thenmozhi, 2014). Hipotesis yang diajukan pada penelitian ini adalah sebagai berikut:

$\mathrm{H}_{3}$ : Terdapat perbedaan kinerja LPD Kecamatan Mengwi dilihat dari perspektif proses bisnis internal.

Perspektif pembelajaran dan pertumbuhan memfokuskan keterampilan dan kepuasan sumber daya manusia. Hipotesis yang diajukan dalam penelitian ini adalah sebagai berikut:

$\mathrm{H}_{4}$ : Terdapat perbedaan kinerja LPD Kecamatan Mengwi dilihat perspektif pembelajaran dan pertumbuhan. 


\section{METODE PENELITIAN}

Penelitian ini merupakan penelitian komparatif yaitu membandingkan kinerja LPD di Kecamatan Mengwi dengan metode balanced scorecard. Menurut Sugiyono (2017:54), pendekatan komparatif merupakan penelitian yang bersifat membandingkan keberadaan satu variabel atau lebih pada dua atau lebih sampel yang berbeda dan menggunakan pendekatan kualitatif dimana pendekatan ini digunakan untuk meneliti populasi dan sampel tertentu.

Penelitian ini dilakukan di LPD yang berada di Kecamatan Mengwi. Obyek dalam penelitian ini adalah kinerja LPD yang berada di Kecamatan Mengwi. Penilaian kinerja LPD dilakukan dengan analisa dengan prinsip balanced scorecard. Penelitian ini menggunakan empat variabel meliputi, (1) perspektif keuangan yang diukur menggunakan rasio (Wiagustini, 2014:90).

$$
R O I=\frac{\text { Laba Bersih }}{\text { Total aktiva }} \times 100 \%
$$

ROI memberikan indikasi jumlah laba yang diperoleh dihubungkan dengan tingkat investasi di total aktiva (Wiagustini, 2014:90), (2) perspektif pelanggan diukur menggunakan jawaban kuesioner yang diberikan kepada nasabah LPD dengan indicator, yaitu: kelengkapan fasilitas LPD dan suasana LPD, kemampuan karyawan memberikan pelayanan, daya tangkap dan kesigapan karyawan, jaminan keamanan di LPD, (3) perspektif proses bisnis internal diukur menggunkan jawaban kuesioner yang diberikan kepada karyawan LPD dengan indikator yaitu: pelaksanaan administrasi sesuai dengan prosedur, ketersediaan sara dan prasarana LPD, (4) persepsi perspektif pertumbuhan dan pembelajaran diukur menggunakan jawaban responden karyawan LPD dengan indicator, yaitu: 
hubungan dengan rekan kerja, penghargaan, komitmen, kondisi kerja. Pernyataan dalam kuesioner nasabah LPD dan Karyawan LPD dinilai menggunakan skala Likert dengan empat jawaban, yaitu: (a) Sangat setuju skor 4, b) Setuju skor 3, c) Tidak setuju skor 2, d) Sangat Tidak Setuju skor 1. Jawaban atas empat kategori tersebut akan digolongkan menjadi 2 pernyataan positif (ya) meliputi jawaban sangat setuju dan setuju, sedangkan untuk pernyataan negatif (tidak), yaitu jawaban tidak setuju dan sangat tidak setuju. Menurut Putri dan Wirasedana, 2015, jika 60-100 persen jawaban responden adalah positif (ya) maka kinerja LPD dapat dikatakan baik, sedangkan jika jawaban responden negatif (tidak) 0-59 persen menjawab positif maka kinerja LPD kurang baik.

Populasi dalam penelitian ini adalah seluruh LPD yang berada di Kecamatan Mengwi Kabupaten Badung. Berdasarkan data yang di peroleh dari LPLPD Kabupaten Badung, terdapat 38 LPD di Kecamatan Mengwi. Pemilihan sampel LPD didasarkan pada metode proportionate stratified random sampling. Pemilihan sampel responden nasabah dan karyawan LPD menggunakan rumus slovin. Responden nasabah LPD berjumlah 100 orang dan responden karyawan berjumlah 75 orang.

Pengujian hipotesis dalam penelitian ini menggunakan Uji ANOVA. Uji ANOVA digunakan untuk menguji lebih dari dua rata-rata populasi, apakah mempunyai rata-rata yang sama atau berbeda. Menurut Sugiyono (2017:174) Pengunaan Analisis Varians dilandasi pada asumsi: sampel diambil secara random, data berdistribusi normal, varians antar sampel homogen.

Pengambilan keputusan didasarkan pada perbandingan nilai probabilitas 
yang dihasilkan model uji dengan nilai tingkat kepercayaan $(\alpha=0,05)$ yang digunakan dalam penelitian ini. Oleh karena itu, kriteria pengujian hipotesis adalah sebagai berikut. Hi diterima jika probabilitas (sig.) $\leq \alpha=0,05$. Hi ditolak jika probabilitas (sig.) $>\alpha=0,05$

\section{HASIL DAN PEMBAHASAN}

Perspektif keuangan merupakan salah satu aspek penting dalam pengukuran kinerja LPD untuk menghasilkan laba. Pengukuran kinerja keuangan LPD dalam penelitian ini menggunakan pendekatan pengukuran kinerja dengan ROI. Data yang digunakan dalam pembahasan ini adalah laba operasional dan total aktiva per 31 Desember 2014 - 31 Desember 2016.

Kemampuan perusahaan untuk memperoleh keuntungan dari keseluruhan aktiva yang dimiliki ditunjukan dengan menggunakan rasio ROI. Berdasarkan hasil perhitungan maka diperoleh nilai rasio ROI LPD Beringkit pada tahun 2014 sebesar 8,86 persen, pada tahun 2015 sebesar 6,97 persen, pada tahun 2016 sebesar 5,60 persen, dan diperoleh nilai rata-rata ROI sebesar 7,14 persen itu menunjukan kemampuan LPD beringkit memperoleh laba dari total akiva menurun pada tahun 2014,2015,2016. Berdasarkan nilai rata-rata ROI LPD Beringkit memperoleh nilai lebih besar dari LPD lainnya itu menunjukkan LPD Beringkit mampu menghasilkan laba dengan total aktiva lebih baik dari LPD lainnya. Hasil perhitungan nilai rasio ROI LPD Lukluk pada tahun 2014 diperoleh sebesar 5,94 persen, pada tahun 2015 sebesar 6,92 persen, pada tahun 2016 sebesar 6,68 persen, dan diperoleh nilai rata-rata ROI sebesar 6,51 persen itu

menunjukan kemampuan LPD Lukluk memperoleh laba dari total aktiva 
cenderung fluktuatif karena pada tahun 2015 nilai ROI meningkat namun pada tahun 2016 nilai ROI menurun.

LPD Mengwi memperoleh nilai rasio ROI pada tahun 2014 sebesar 6,90 persen, pada tahun 2015 sebesar 5,94 persen, pada tahun 2016 sebesar 5,47 persen dengan nilai rata-rata ROI sebesar 6,10 persen itu menunjukkan kemampuan LPD Mengwi memperoleh laba dari total aktiva menurun pada tahun 2014, 2015, 2016. Hasil perhitungan nilai ROI LPD Buduk menunjukan kemamuan LPD Buduk menghasilkan laba dari total aktiva pada tahun 2014, 2015, 2016 menurun dengan perolehan nilai ROI pada tahun 2014 sebesar 6,02 persen, pada tahun 2015 sebesar 5,05 persen, pada tahun 2016 sebesar 4,77 persen dengan nilai rata-rata ROI sebesar 5,28 persen.

Hasil perhitungan nilai ROI LPD Karangenjung menunjukkan adanya peningkatan kemampuan LPD Karangenjung menghasilkan laba melalui total aktiva pada tahun 2015 sebesar 7,63 persen, namun pada tahun 2016 nilai ROI LPD Karangenjung menurun sebesar 3,61 persen itu menunjukkan adanya penurunan kemampuan LPD Karangenjung menghasilkan laba dari total aktiva. Hasil perhitungan ROI LPD Munggu menunjukkan kemampuan LPD Munggu menghasilkan laba melalui total aktiva menurun pada taghun 2014,2015,2016 dengan nilai ROI pada tahun 2014 sebesar 5,08 persen, pada tahun 2015 sebesar 4,79 persen, pada tahun 2016 sebesar 4,38 persen.

Berdasarkan perhitungan nilai ROI menunjukkan kemampuan LPD Kwanji menghasilkan laba melalui total aset menurun pada tahun 2014 sebesar 5,83 persen, pada tahun 2015 sebesar 3,74 persen, pada tahun 2016 sebesar 3,67 
persen. Hasil perhitungan nilai ROI LPD Parerenan pada menunjukkan kemamuan LPD Parerenan menghasilkan laba dari total aktiva menurun pada tahun 2014, 2015, 2016 dengan perolehan nilai ROI pada tahun 2014 sebesar 4,59 persen, pada tahun 2015 sebesar 4,47 persen, pada tahun 2016 sebesar 4,15 persen dengan nilai rata-rata ROI sebesar 4,40 persen.

Hasil perhitungan nilai ROI LPD Sempidi menunjukan adanya peningkatan kemampuan LPD Sempidi menghasilkan laba melalui total aktiva pada tahun 2015 sebesar 4,52 persen, namun pada tahun 2016 nilai ROI LPD Sempidi menurun menjadi 4,38 persen itu menunjukkan adanya penurunan kemampuan LPD Sempidi menghasilkan laba dari total aktiva. Hasil perhitungan nilai ROI LPD Banjar Sayan menunjukkan adanya peningkatan kemampuan LPD Banjar Sayan menghasilkan laba melalui total aktiva pada tahun 2015 sebesar 4,53 persen, namun pada tahun 2016 nilai ROI LPD Banjar Sayan menjadi 4,15 persen itu menunjukan adanya penurunan kemampuan LPD Banjar Sayan menghasilkan laba dari total aktiva.

Hasil perhitungan nilai ROI LPD Sading menunjukkan kemamuan LPD Sading menghasilkan laba dari total aktiva menurun pada tahun 2014, 2015,2016 dengan perolehan nilai ROI pada tahun 2014 sebesar 4,46 persen, pada tahun 2015 sebesar 4,35 persen, pada tahun 2016 sebesar 3,70 persen dengan nilai ratarata ROI sebesar 4,17 persen. Hasil perhitungan nilai ROI LPD Cemenggon menunjukan kemamuan LPD Cemenggon menghasilkan laba dari total aktiva menurun pada tahun 2014, 2015, 2016 dengan perolehan nilai ROI pada tahun 2014 sebesar 4,56 persen, pada tahun 2015 sebesar 4,12 persen, pada tahun 2016 
sebesar 3,55 persen dengan nilai rata-rata ROI sebesar 4,08 persen.

Hasil perhitungan nilai ROI LPD Sobangan menunjukan adanya peningkatan kemampuan LPD Sobangan menghasilkan laba melalui total aktiva pada tahun 2015 sebesar 4,17 persen, namun pada tahun 2016 nilai ROI LPD Sobangan menjadi 4,12 persen itu menunjukan adanya penurunan kemampuan LPD Sobangan menghasilkan laba dari total aktiva. Hasil perhitungan nilai ROI LPD Balangan menunjukan kemampuan LPD Balangan menghasilkan laba melalui total aktiva pada tahun 2015 menurun menjadi 3,80 persen, namun pada tahun 2016 nilai ROI LPD Balangan menjadi 3,93 persen itu menunjukan adanya peningkatan kemampuan LPD Balangan menghasilkan laba dari total aktiva.

Hasil perhitungan nilai ROI LPD Tumbak Bayuh menunjukkan adanya peningkatan kemampuan LPD Tumbak Bayuh menghasilkan laba melalui total aktiva pada tahun 2015 menjadi 3,83 persen, namun pada tahun 2016 nilai ROI LPD Tumbak Bayuh menjadi 3,48 persen itu menunjukan kemampuan LPD Tumbak Bayuh menghasilkan laba dari total aktiva turun dari tahun sebelumnya. Hasil perhitungan nilai ROI LPD Abianbase menunjukkan adanya peningkatan kemampuan LPD Abianbase menghasilkan laba melalui total aktiva pada tahun 2014 sebesar 2,92 persen, pada tahun 2015 menjadi 3,27 persen, dan pada tahun 2016 meningkat menjadi 3,59 persen itu menunjukkan adanya peningkatan kemampuan LPD Abianbase menghasilkan laba dari total aktiva setiap tahunnya.

Hasil perhitungan nilai ROI LPD Mengening menunjukkan adanya peningkatan kemampuan LPD Mengening menghasilkan laba melalui total aktiva pada tahun 2015 sebesar 4,52 persen, namun pada tahun 2016 nilai ROI LPD 
Mengening menjadi 4,38 persen itu menunjukan adanya penurunan kemampuan LPD Mengening menghasilkan laba dari total aktiva. Hasil perhitungan nilai ROI LPD Semate menunjukan adanya peningkatan kemampuan LPD Semate menghasilkan laba melalui total aktiva pada tahun 2015 menjadi 3,17 persen, namun pada tahun 2016 nilai ROI LPD Semate menjadi 3 persen itu menunjukkan adanya penurunan kemampuan LPD Semate menghasilkan laba dari total aktiva.

Hasil perhitungan nilai ROI LPD Anggungan menunjukan adanya penurunan kemamuan LPD Anggungan menghasilkan laba dari total aktiva pada tahun 2014, 2015, 2016 dengan perolehan nilai ROI pada tahun 2014 sebesar 2,09 persen, pada tahun 2015 sebesar 1,99 persen, pada tahun 2016 sebesar 1,98 persen dengan nilai rata-rata ROI sebesar 2,01 persen. Berdasarkan hasil perhitungan maka diperoleh nilai rasio ROI LPD Gulingan pada tahun 2014 sebesar 1,78 persen, pada tahun 2015 sebesar 1,82 persen, pada tahun 2016 sebesar 2,21 persen, dan diperoleh nilai rata-rata ROI sebesar 1,94 persen itu menunjukkan kemampuan LPD Gulingan memperoleh laba dari total akiva meningkat pada tahun 2014, 2015, 2016 namun berdasarkan nilai rata-rata ROI LPD Gulingan memperoleh nilai lebih kecil dari LPD lainnya itu menunjukkan LPD Gulingan memiliki kemampuan menghasilkan laba dengan total aktiva tidak sebaik LPD lainnya.

Berdasarkan hasil perhitungan nilai ROI pada pada tahun 2014 LPD Beringkit memperoleh nilai ROI lebih tinggi dari LPD lainnya. Pada tahun 2015 LPD Karangenjung memiliki kemampuan menghasilkan laba melalui total aktiva lebih baik dari LPD lainnya. Pada tahun 2016 LPD Lukluk memiliki kemampuan 
menghasilkan laba melalui total aktiva lebih baik dari LPD lainnya. Namun berdasarkan perhitungan rata-rata ROI LPD Beringkit memiliki kemampuan menghasilkan laba melalu total aktiva lebih baik dari LPD lainnnya.

Berdasarkan jawaban responden dapat dijelaskan bahwa dari perspektif pelanggan yang diukur dengan indikator kelengkapan fasilitas LPD, pelayanan karyawan LPD, kesigapan karyawan LPD, jaminan keamanan, kepedulian karyawan LPD dilihat dari proporsi pernyataan positif dan negatif responden. Berdasarkan jawaban responden LPD Mengening, LPD Sempidi, LPD Kwanji, LPD Parerenan, LPD Tumbak Bayuh, LPD Abianbase, LPD Buduk, LPD Banjar Sayan, LPD Gulingan, LPD Sading, LPD Lukluk, LPD Beringkit, LPD Karangenjung, LPD Sobangan, LPD Balangan, LPD Cemenggon, LPD Semate mendapat proporsi pernyataan positif sebesar 100 persen itu menunjukkan LPD berada pada kualifikasi baik. Proporsi tersebut menunjukan tingkat kepuasan nasabah LPD pada fasilitas LPD, pelayanan karyawan LPD, kesigapan karyawan LPD, jaminan keamanan, serta kepedulian karyawan LPD yang baik.

Berdasarkan jawaban responden nasabah, LPD Munggu mendapat proporsi pernyataaan positif sebesar 98 persen dan negatif sebesar 2 persen. Proporsi tersebut menunjukkan adanya ketidakpuasan nasabah LPD yaitu pada jaminan keamanan namun LPD Munggu masi berada pada kualifikasi baik karena proporsi pernyataan positif lebih dari 60 persen. Berdasarkan jawaban responden nasabah, LPD Mengwi mendapat proporsi pernyataan positif sebesar 92 persen dan proporsi pernyataan negatif sebesar 8 persen. Proporsi tersebut menunjukkan adanya ketidakpuasan nasabah LPD pada fasilitas LPD, pelayanan karyawan 
LPD, jaminan keamanan. LPD Mengwi masi berada pada kualifikasi baik karena mendapat proporsi pernyataan positif lebih dari 60 persen, yaitu sebesar 92 persen.

Berdasarkan jawaban responden nasabah, LPD Anggungan mendapat proporsi pernyataan positif sebesar 94 persen dan proporsi pernyataan negatif sebesar 6 persen. Proporsi tersebut menunjukkan adanya ketidakpuasan nasabah LPD pada fasilitas dan suasana LPD dan jaminan keamanan. LPD Anggungan masih berada pada kualifikasi baik karena mendapat proporsi pernyataan positif lebih dari 60 persen, yaitu sebesar 94 persen. Berdasarkan hasil analisis menunjukkan adanya perbedaan tingkat kepuasan nasabah dari kinerja masingmasing LPD di Kecamatan Mengwi. Proporsi pernyataan positif yang diperoleh LPD Munggu, LPD Anggungan, LPD Mengwi lebih kecil dari LPD lainnya, namun kinerja perspektif pelanggaan masih berada pada kualifikasi baik. Kinerja dari perspektif proses bisnis internal LPD di Kecamatan Mengwi diukur dari indikator-indikator tingkat kepuasan karyawan terhadap LPD tempatnya bekerja, pelaksanaan administrasi sesuai prosedur, dan persepsi karyawan atas suatu proses penyusunan kegiatan.

Berdasarkan jawaban responden, dapat dijelaskan bahwa rata-rata responden karyawan LPD di Kecamatan Mengwi memberikan pernyataan positif sebesar 100,00 persen dan pernyataan negatif sebesar 0,00 persen. Berdasarkan jawaban responden proporsi pernyataaan positif lebih dari 60 persen sehingga LPD di Kecamataan Mengwi berada pada kualifikasi baik. Perbedaan kinerja pada perspektif ini terlihat dari kemampuan masing-masing LPD untuk mendukung 
peningkatan kualitas pelayanan, seperti prosedur simpan pinjam, ketersediaan sarana dan prasarana serta mempunyai perencanaan yang sistematis dalam upaya untuk mendukung pelaksanaan dan evaluasi pada akhir kegiatan.

Berdasarkan hasil analisis kinerja perspektif pembelajaran dan pertumbuhan, LPD Mengening, LPD Sempidi, LPD Tumbak Bayuh, LPD Abianbase, LPD Mengwi, LPD Banjar Sayan, LPD Gulingan, LPD Anggungan, LPD Beringkit, LPD Balangan, LPD Cemenggon, LPD Semate, memperoleh proporsi pernyataan positif sebesar 100 persen itu berarti LPD tersebut berada pada kualifikasi baik. Proporsi pernyataan positif tersebut menunjukan tingkat kepuasan karyawan pada hubungan dengan rekan kerja, penghargaan yang diberikan LPD, komitmen karyawan, serta fasilitas kerja yang disediakan LPD.

Berdasarkan jawaban responden karyawan, LPD Munggu memperoleh proporsi pernyataan positif lebih dari 60 persen, yaitu sebesar 92 persen itu menunjukan kinerja LPD Munggu berada pada kualifikasi baik. LPD Munggu memperoleh proporsi pernyataan negatif sebesar 8 persen, proporsi tersebut menunjukan adanya ketidakpuasan karyawan LPD Munggu pada penghargaan yang diberikan LPD, kurangnya komitmen karyawan serta hubungan yang kurang baik antar karyawan.

Berdasarkan jawaban responden karyawan, LPD Kwanji memperoleh proporsi pernyataan positif lebih dari 60 persen, yaitu sebesar 94 persen itu menunjukan kinerja LPD Kwanji berada pada kualifikasi baik. LPD Kwanji memperoleh proporsi pernyataan negatif sebesar 6 persen, proporsi tersebut menunjukkan adanya ketidakpuasan karyawan LPD Kwanji pada penghargaan 
yang diberikan LPD. Berdasarkan jawaban responden karyawan, LPD Parerenan memperoleh proporsi pernyataan positif lebih dari 60 persen, yaitu sebesar 92 persen itu menunjukkan kinerja LPD Parerenan berada pada kualifikasi baik. LPD Parerenan memperoleh proporsi pernyataan negatif sebesar 8 persen, proporsi tersebut menunjukkan adanya ketidakpuasan karyawan LPD Parerenan pada penghargaan yang diberikan LPD.

Berdasarkan jawaban responden karyawan, LPD Buduk memperoleh proporsi pernyataan positif lebih dari 60 persen, yaitu sebesar 96 persen itu menunjukan kinerja LPD Buduk berada pada kualifikasi baik. LPD Buduk memperoleh proporsi pernyataan negatif sebesar 4 persen, proporsi tersebut menunjukkan adanya ketidak puasan karyawan LPD Buduk pada penghargaan yang diberikan LPD dan hubungan yang kurang baik antar karyawan.

Berdasarkan jawaban responden karyawan, LPD Sading memperoleh proporsi pernyataan positif lebih dari 60 persen yaitu sebesar 96 persen itu menunjukan kinerja LPD Sading berada pada kualifikasi baik. LPD Sading memperoleh proporsi pernyataan negatif sebesar 4 persen, proporsi tersebut menunjukkan adanya ketidakpuasan karyawan LPD Sading pada kondisi kerja seperti kurangnya waktu istirahat. Berdasarkan jawaban responden karyawan, LPD Lukluk memperoleh proporsi pernyataan positif lebih dari 60 persen, yaitu sebesar 98 persen itu menunjukkan kinerja LPD Lukluk berada pada kualifikasi baik. LPD Lukluk memperoleh proporsi pernyataan negatif sebesar 2 persen, proporsi tersebut menunjukkan adanya ketidakpuasan karyawan LPD Lukluk pada penghargaan yang diberikan LPD, kurangnya komitmen karyawan serta hubungan 
yang kurang baik antar karyawan.

Berdasarkan jawaban responden karyawan, LPD Karangenjung memperoleh proporsi pernyataan positif lebih dari 60 persen, yaitu sebesar 93 persen itu menunjukkan kinerja LPD Karangenjung berada pada kualifikasi baik. LPD Karangenjung memperoleh proporsi pernyataan negatif sebesar 7 persen, proporsi tersebut menunjukkan adanya ketidakpuasan karyawan LPD Karangenjung pada kondisi kerja seperti kurangnya waktu istirahat. Berdasarkan jawaban responden karyawan, LPD Sobangan memperoleh proporsi pernyataan positif lebih dari 60 persen, yaitu sebesar 96 persen itu menunjukkan kinerja LPD Sobangan berada pada kualifikasi baik. LPD Sobangan memperoleh proporsi pernyataan negatif sebesar 4 persen, proporsi tersebut menunjukkan adanya ketidak puasan karyawan LPD Sobangan pada kondisi kerja seperti kurangnya waktu istirahat, kurangnya komitmen karyawan serta hubungan yang kurang baik antar karyawan. Berdasarkan hasil analasis menunjukkan bahwa terdapat perbedaan kemampuan sumber daya manusia dalam meningkatkan kualitas pelayanan, dalam hal ini yang dilihat adalah upaya-upaya yang dilakukan untuk meningkatkan kualitas serta kemampuan karyawan.

Berdasarkan hasil analisis statistik diperoleh nilai signifikansi sebesar $0,000<\operatorname{alph} a(\alpha=0,05)$, hal ini berarti $\mathrm{H}_{1}$ diterima. Dapat disimpulkan bahwa kinerja masing-masing LPD di Kecamatan Mengwi memiliki perbedaan yang signifikan dilihat dari rasio ROI. Perbedaan ini menunjukan kemampuan LPD untuk menghasilkan laba bersih melalui total aktiva perusahaan berbeda-beda. Berdasarkan hasil perhitungan rata- rata nilai ROI LPD Beringkit lebih tinggi dari 
LPD lainnya itu menunjukkan kemampuan LPD Beringkit untuk menghasilkan Laba bersih melalui total aktiva lebih baik dari LPD lainnya.

Berdasarkan hasil analisis nilai signifikansi pada tabel 4.18 sebesar 0,000 <alpha $(\alpha=0,05)$, hal ini berarti bahwa $\mathrm{H}_{2}$ diterima. Dapat disimpulkan bahwa kinerja masing-masing LPD di Kecamatan Mengwi memiliki perbedaan yang signifikan dilihat perspektif pelanggan. Berdasarkan jawaban responden nasbah LPD, adanya perbedaan tingkat kepuasan nasabah LPD di Kecamatan Mengwi karena tingkat pelayanan yang berbeda.

Oleh karena nilai signifikansi pada tabel 4.19 sebesar $0,001<$ alpha $(\alpha=$ 0,05), hal ini berarti bahwa $\mathrm{H}_{3}$ diterima. Oleh karena itu dapat disimpulkan bahwa kinerja masing-masing LPD di Kecamatan Mengwi memiliki perbedaan yang signifikan dilihat perspektif proses internal. Berdasarkan jawaban responden perbedaan terdapat perbedaan pengawasan dari atasan terhadap cara kerja karyawan dan adanya perbedaan tindakan perhatian dari atasan terhadap fasilitas kantor yang mempengaruhi kinerja karyawan.

Hasil analisis statistik diperoleh nilai signifikansi pada tabel 4.20 sebesar $0,003<\operatorname{alpha}(\alpha=0,05)$, hal ini berarti bahwa $\mathrm{H}_{4}$ diterima. Oleh karena itu dapat disimpulkan bahwa kinerja masing-masing LPD di Kecamatan Mengwi memiliki perbedaan yang signifikan dilihat perspektif pembelajaran dan pertumbuhan. Berdasarkan jawaban responden terdapat perbedaan tingkat kepuasan karyawan terhadap penghargaan yang diberikan LPD pada karyawan dan perbedaan tingkat kepuasan dari kondisi dan rekan kerja masing-masing LPD.

Penelitian ini diharapkan dapat memberikan kontribusi mengenai analisis 
komparatif kinerja pada Lembaga Perkreditan Desa Kecamatan Mengwi dengan metode balanced scorecard. Hasil uji dalam penelitian ini ditemukan bahwa terdapat perbedaan kinerja dari masing-masing LPD di Kecamatan Mengwi dilihat dari perspektif keuangan, perspektif pelanggan, perspektif proses bisnis internal, daan perspektif pembelajaran dan pertumbuhan.

Konsep balanced scorecard merupakan kinerja perusahaan untuk mencapai keberhasilan kompetitif yang dilihat dari 4 pespektif. Dalam penelitian ini terdapat perbedaan kinerja persprekif keuangan yang diukur dengan rasio ROI, LPD Beringkit merupakan LPD yang memperoleh ROI 7,14 perssen lebih besar dibandingkan LPD. Terdapat perbedaan kinerja perspektif pelanggan pada LPD di Kecamatan Mengwi sehinggga LPD harus mampu meningkatkan pelayanan karena pelanggan merupakan komponen penting pada suatu perusahaan dalam mencapai tujuan keuangan perusahaan tersebut. Pemahaman atas kinerja perspektif proses bisnis internal memungkinkan bagi organisasi untuk melakukan identifikasi bertahap cara pengelolaan sumber daya internal secara optimal. Perspektif pembelajaran dan pertumbuhan pada perusahaan menitikberatkan pada kesejahteraan karyawan dan meningkatkan pengetahuan karyawan karena dengan meningkatnya pengetahuan karyawan akan meningkat pula kemampuan karyawan untuk berpartisipasi dalam mencapai tujuan perusahaan. Tujuan dalam perspektif pembelajaran dan pertumbuhan adalah memberikan sarana yang memungkinkan tujuan-tujuan dalam ketiga perspektif (perspektif keuangan, perspektif pelanggan, perspektif proses bisnis internal) tercapai.

\section{SIMPULAN}

Berdasarkan hasil penelitian yang diperoleh melalui analisis dan pengujian statistik serta pembahasan maka dapat disimpulkan bahwa: terdapat perbedaan kinerja keuangan (ROI) pada LPD di Kecamatan Mengwi. LPD Beringkit memiliki kemampuan menghasilkan laba melalui total aktiva lebih baik dari LPD lainnya, terdapat perbedaan kinerja dari perspektif pelanggan atau nasabah pada LPD Kecamatan Mengwi. Secara keseluruhan kinerja perspektif pelanggan pada 
LPD di Kecamatan Mengwi berada pada kualifikasi baik dengan rata-rata pernyataan positif responden sebesar 99,20 persen, terdapat perbedaan kinerja dari perspektif proses bisnis internal pada LPD Kecamatan Mengwi. Berdasarkan jawaban responden seluruh LPD di Kecamatan Mengwi berada padaa kualifikasi baik, terdapat perbedaan kinerja dari perspektif pembelajaran dan pertumbuhan Pada LPD Kecamatan Mengwi. Secara keseluruhan menunjukkan kinerja berada pada kualifikasi baik dengan meihat rata-rata proposi pernyataan positif responden seebesar 97,79 persen. Secara statistik dapat dibuktikan bahwa terdapat perbedaan kinerja dari masing-masing LPD di Kecamatan Mengwi dilihat dari perspektif keuangan, perspektif pelanggan, perspektif proses bisnis internal, dan perspektif pembelajaran dan pertumbuhan.

Berdasarkan hasil penelitian dan simpulan di atas, maka saran yang dapat diberikan adalah bagi keseluruhan LPD yang ada di Kecamatan Mengwi diharapkan memperhatikan hasil penilaian kinerja LPD dengan menggunakaan metode Balanced Scorecard sebagai alat ukur kinerja kedepannya. LPD di Kecamatan Mengwi diharapkan mampu mempertahankan bahkan meningkatkan kinerja saat ini, karena masih terdapat ketidakpuasan responden nasabah pada sikap karyawan, jaminan keamanaan serta kurangnya sarana dan prasarana yang dimiliki khususnya pada LPD Mengwi. LPD di Kecamatan Mengwi diharapkan mampu mempertahankan kinerja yang saat ini sudah sangat baik, bahkan jika memungkinkan agar dapat ditingkatkan lagi demi mempertahankan kepuasan pelanggan LPD. 
Pada perspektif pembelajaran dan pertumbuhan, LPD yang ada di Kecamatan Mengwi mampu mempertahankan bahkan lebih meningkatkan kinerja saat ini. Pada perspektif pembelajaran dan pertumbuhan LPD diharapkan lebih memperhatikan kepuasan karyawan, karena masih terdapat ketidakpuasan karyawan pada penghargaan, kondisi kerja serta hubungan antar karyawan. Penelitian ini hanya melihat perbedaan kinerja dari sisi hasil pengujian statistik dan perhitungan saja tanpa menelusuri lebih dalam penyebab dari perbedaan tersebut. Untuk itu, disarankan penelitian selanjutnya untuk melihat lebih dalam perbedaan tersebut dengan menggunakan metode yang berbeda.

\section{REFERENSI}

A., Seth. dan A., Oyugi. L. (2013) 'Influence of Balanced Scorecard on Organizational Performance in Institutions of Higher Learning in Kenya. A Case Study of University of Nairobi', International Journal of Education and Research, 1(8), pp. 1-12.

Al-Najjar, S. M. dan Kalaf, K. H. (2012) 'Designing a Balanced Scorecard to Measure a Bank's Performance: A Case Study’, International Journal of Business Administration, 3(4), pp. 44-53. doi: 10.5430/ijba.v3n4p44.

Antara, I. G. A., Bagia, I. W. dan Cipta, W. (2014) 'Pengaruh Tabungan dan Kredit Bermasalah Terhadap Laba Pada Lembaga Perkreditan Desa (LPD)', e-Journal Bisma Universitas Pendidikan Ganesha Jurusan Manajemen, 2(1).

Antari, N. W. Y. dan Sudana, I. P. (2016) 'Strategi dan Pengukuran Kinerja Badan Rumah Sakit Umum Tabanan Dengan Pendekatan Balance Scorecard', E-Jurnal Akuntansi Universitas Udayana, 15(3), pp. 2240-2268.

Ariani, M. W. dan Ardiana, P. A. (2015) 'Pengaruh Kecukupan Modal, Tingkat Efisiensi, Resiko Kredit, dan Likuiditas pada Profitabilitas LPD Kabupaten Badung', E-Jurnal Akuntansi Universitas Udayana, 1, pp. 259-275.

Atkinson, Anthony A., Robert S Kaplan, Ella Mae Matsumura dan S. Mark Young. (Nayla M. Tazkiyah, Penerjemah). 2012. Akuntasi Manajemen Edisi ke 5. Jakarta: PT Indeks. 
Begawan, T. A. dan Suryanawa, I. K. (2013) "Analisis Kinerja Dengan Pendekatan Balanced Scorecard Pada The Coffee Bean And Tea Leaf Cabang Bali," E-Jurnal Akuntansi Universitas Udayana, 2(1), pp. 1-18.

Christina, Ni Putu Yessy dan Sudana, I. P. (2013) 'Penilaian Kinerja Pada PT. Adhi Karya dengan Pendekatan Balanced Scorecard', E-Jurnal Akutansi Universitas Udayana, 3(5), pp. 516-529.

Dincer, H., Hacioglu, U. dan Yuksel, S. (2016) 'Balanced Scorecard-based Performance Assessment of Turkish Banking Sector with Analytic Network Process', International Journal of Decision Sciences \& Applications-IJDSA, 1(1), pp. 1-21.

Domanovic, V. (2016) 'The Effects of the Integrated Application of BSC and ABM to Enterprise Strategy and Efficiency', Ekonomski horizonti, 18(2), pp. 153-167. doi: 10.5937/ekonhor1602153D.

Dudin, M. N. dan Frolova, E. E. evna (2015) 'The Balanced Scorecard as a Basis for Strategic Company Management in the Context of the World Economy Transformation', Asian Social Science, 11(3), pp. 282-288. doi: 10.5539/ass.v11n3p282.

Gunawan, K. (2009) 'Analisis Faktor Kinerja Organisasi Lembaga Perkreditan Desa di Bali (Suatu Pendekatan Perspektif Balanced Scorecard)', Jurnal Manajemen dan Kewirausahaan, 11(2), pp. 172-182.

Harold, L. dan Thenmozhi, M. (2014) 'An Integrated Performance Success Measurement Framework For Evaluating Banking System Success: An Empirical Study', Journal of Performance Management, 25(3), pp. 28-55.

Istiqlal, C. H. (2009) 'Penilaian Kinerja Perbankan Syariah Dengan Metode Balanced Scorecard', Jurnal tentang BSC, III(2), pp. 167-180.

Kaplan. R dan D. Norton. 2000. Balanced Scorecard : Menerapkan Strategi Menjadi Aksi - Balanced Scorecard. Diterjemahkan oleh Peter R. Yosi Pasla Erlangga, Jakarta

Limbu, W. P. dan Sisdyani, E. A. (2016) 'Evaluasi Kinerja Dinas Pendapatan Daerah Kota Denpasar Berbasis Balanced Scorecard', E-Jurnal Akuntansi Universitas Udayana, 15, pp. 1682-1710.

Lin, Y. H. Chih-Cheng Chen, dan Chuck F.M. (2014) 'Balanced Scorecard Performance Evaluation in a Closed-loop Hierarchical Model Under Uncertainty', Applied Soft Computing, 24, pp. 1022-1032. doi: 10.1016/j.asoc.2014.08.029.

Mulyadi. 2007. Akuntansi Manajemen. Edisi ke- 3. Jakarta: Salemba Empat 
Öztürk, E. dan Coskun, A. (2014) 'A Strategic Approach to Performance Management in Banks: The balanced scorecard', Accounting and Finance Research, 3(3), pp. 151-158.

Panicker, S. dan Seshadri, V. (2013) 'Devising a Balanced Scorecard to determine Standard Chartered Bank's Performance: A Case Study', International Journal of Business Research and Development ISSN, 2(2), pp. 35-42.

Peraturan Daerah Propinsi Bali no.3 tahun 2017. Tentang Perubahan atas Peraturan Daerah Propinsi Bali no.8 tahun 2002 tentang Lembaga Perkreditan Desa.

Poureisa, A., Ahmadgourabi, M. B. A. dan Efteghar, A. (2013) 'Balanced Scorecard: A New Tool For Performance Evaluation', Interdisciplinary Journal of Contemporary Research in Business, 5(1), pp. 974-978.

Purwandari, D. (2016) 'Evaluasi Penerapan Balanced Scorecard sebagai Pendekatan dalam Pengukuran Kinerja', Jurnal Buana Akuntansi, 1(1), pp. $23-46$.

Putri, I. G. A. P. D. dan Wirasedana, I. W. P. (2015) 'Analisis Perbandingan Penilaian Kinerja BPR dengan Pendekatan Balanced Scorecard', E-Jurnal Akuntansi Universitas Udayana, 1, pp. 1-19.

Rasmini, N. K., Supadmi, N. L. dan Sucandra, N. L. P. H. (2009) 'Penilaian Kinerja Badan Rumah Sakit Umum Tabanan Berdasarkan Balanced Scorecard', Jurnal Ilmiah Akuntasi dan Bisnis, 6(2), pp. 1-22.

Sari, A. . S. V. K. dan Putri, I. G. A. M. A. D. (2014) 'Perbandingan Kinerja PT. Amanaid dan PT. Enviro Sejahterah Abadi dengan Menggunakan Balanced Scorecard', E-Jurnal Akuntansi Universitas Udayana, 7(2), pp. 357-371.

Suartana, I. W. dan Ariyanto, D. (2012) 'Analisis Kinerja Internal, Balanced Scorecard dan Pengembangan Keuangan Mikro Berkelanjutan (Studi pada Lembaga Perkreditan Desa di Provinsi Bali)', Jurnal Akuntasi \& Auditing, 9(1), pp. 56-69.

Sugiyono. 2017. Metode Penelitian Bisnis. Bandung: Alfabeta.

Sukma, N. P. dan Krisnadewi, K. A. (2013) 'Penilaian Kinerja Berbasis Balanced Scorecard pada Bank Utama', E-Jurnal Akutansi Universitas Udayana, 2(5), pp. 497-515.

Susila, G. P. A. (2016) 'Pengukuran Kinerja Lembaga Perkreditan Desa (LPD) Kecamatan Susut dengan Analisis BALANCED SCORECARD', Jurnal Ilmu Sosial dan Humaniora, 5(2), pp. 810-816.

Undang- undang LKM No.1 Tahun 2013. Tentangg Lembaga Keuanngan Mikro. 
Visitra, Irene Indah (2013) 'Perbandingan Kinerja KSU Kuta Mimba dan PUSKUD Bali Dwipa Menggunakan Balanced Scorecard', E-Jurnal Akuntansi Universitas Udayana, 2, pp. 229-247.

Wiagustini, Ni luh Putu. 2010. Dasar-Dasar Manajemen Keuangan. Denpasar. Udayana University Press.

Widiastiti, K. Y. dan Yadnyana, I. K. (2013) 'Analisis Perbandingan Kinerja PT. BPR Mitra Balijaya Mandiri dan PT. BPR Cahaya Bina Werdhi dengan Pendekatan Balanced Scorecard', E-Jurnal Akuntansi Universitas Udayana, 3, pp. 605-621.

Wiguna, I. G. E. P. dan Wirawati, N. G. P. (2017) "Penerapan Balanced Scorecard Pada Pengukuran Kinerja Trans Sarbagita," E-Jurnal Akuntansi Universitas Udayana, 21(2), pp. 1072-1100.

Winata, I. G. K. A. dan Astana, G. M. O. (2017) 'Menciptakan Keunggulan Bersaing Berkelanjutan LPD Melalui Sumber Daya, Strategi dan Kinerja Operasi (Studi Kasus LPD di Kabupaten Buleleng)', E-Jurnal Ekonomi dan Bisnis Universitas Udayana, 2, pp. 656-671. 